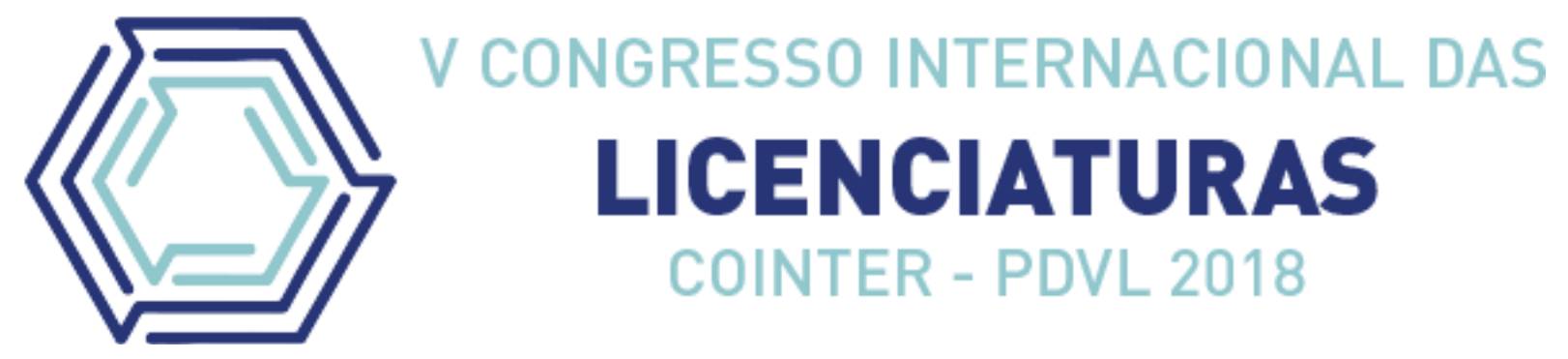

\title{
TRANSVERSALIDADE: O ENSINO DE FORMAS GEOMÉTRICAS A PARTIR DE PLACAS DE SINALIZAÇÃO DE TRÂNSITO
}

\section{TRANSVERSALITY: THE TEACHING OF GEOMETRIC FORMS PART OF TRANSIT SIGNALING PLATES}

\author{
Apresentação: Relato de Experiência \\ Rosana Maria da Silva ${ }^{1}$; Ricardo Sérgio da Silva ${ }^{2}$ \\ DOI: https://doi.org/10.31692/2358-9728.VCOINTERPDVL.2018.00323
}

\section{Introdução}

Os crescentes números de acidentes no trânsito nos fazem refletir sobre essa problemática e nos levam a promover estratégias para combatê-los. A exemplo disso tem-se a proposta de educação no trânsito nas escolas, dessa maneira, a educação para a cidadania no trânsito não deve ser trabalhada separada das demais áreas, pois é um tema transversal e pode ser tido como um recurso de aprendizagem (ALMEIDA, 2014).

A proposta didática a partir de um tema transversal possibilita que o aluno relacione o conteúdo estudado com seu contexto social e construa uma aprendizagem significativa, desse modo os Parâmetros Curriculares Nacionais - PCN (1998) propõem que os conteúdos matemáticos, nesta perspectiva, podem contribuir para o processo de ensino e aprendizagem e proporciona subsídios para que a escola apresente questões de urgência social numa perspectiva de transversalidade e aponte para o compromisso a ser partilhado pelos professores das áreas sociais que têm natureza diferente das áreas convencionais.

As formas geométricas são apresentadas desde os anos iniciais do ensino fundamental e para sua concretização é necessário que o conceito seja relacionado aos contextos sociais, de modo a ser construído de maneira significativa. Desta forma o objetivo do trabalho foi investigar a proposta de ensino de formas geométricas a partir de placas de sinalização de trânsito no $6^{\circ}$ ano do ensino fundamental.

\section{Relato de Experiência}

\footnotetext{
${ }^{1}$ Licenciatura em Matemática, UPE, rosanamaria386@gmail.com

${ }^{2}$ Mestre em Morfotecnologia, UFPE, profricardosergio.bio@gmail.com
} 
As formas geométricas podem ser identificadas em diversas situações em nosso cotidiano, seja em flores, animais, obras de artes, entre outros. Essa percepção contribui para que o estudante se torne participante ativo no processo de aprendizagem e construa suas próprias percepções a respeito do conhecimento (RANCAN, 2011).

A educação para o trânsito aborda problemas sociais e oportuniza discussões a respeito dos acidentes que envolvem condutores e pedestres. Para Banaszeski e Ecco,

\begin{abstract}
educar para o trânsito é preservar a vida, evitar acidentes, exercer a cidadania, no qual respeito, cortesia, cooperação, solidariedade e responsabilidade constituem os eixos determinantes da transformação do comportamento do homem no trânsito.(2009, p. 4)
\end{abstract}

As atividades educativas no trânsito podem contribuir para que os estudantes desenvolvam responsabilidades na sociedade. Nessa perspectiva, a experiência foi vivenciada em uma escola da rede municipal de Passira/PE, com 40 estudantes de uma turma do $6^{\circ}$ ano. Os estudantes foram divididos em equipes, inicialmente sensibilizamos sobre os acidentes no trânsito e sobre a importância da observação das placas de sinalização tanto pelos condutores quanto pelos pedestres. Em seguida buscou-se resgatar os conhecimentos prévios que os alunos possuíam em relação as formas geométricas planas. Foi proposto que as equipes identificassem as placas geométricas que se assemelhassem a figuras geométricas, enfatizando sua importância e o tipo do polígono que a placa representava. Por fim, os estudantes elaboraram cartazes (figura 1), nos quais abordavam as placas de sinalização e suas respectivas formas geométricas.

Figura 1- Elaboração de cartazes relacionando as formas geométricas às placas de sinalização. Fonte: Própria.

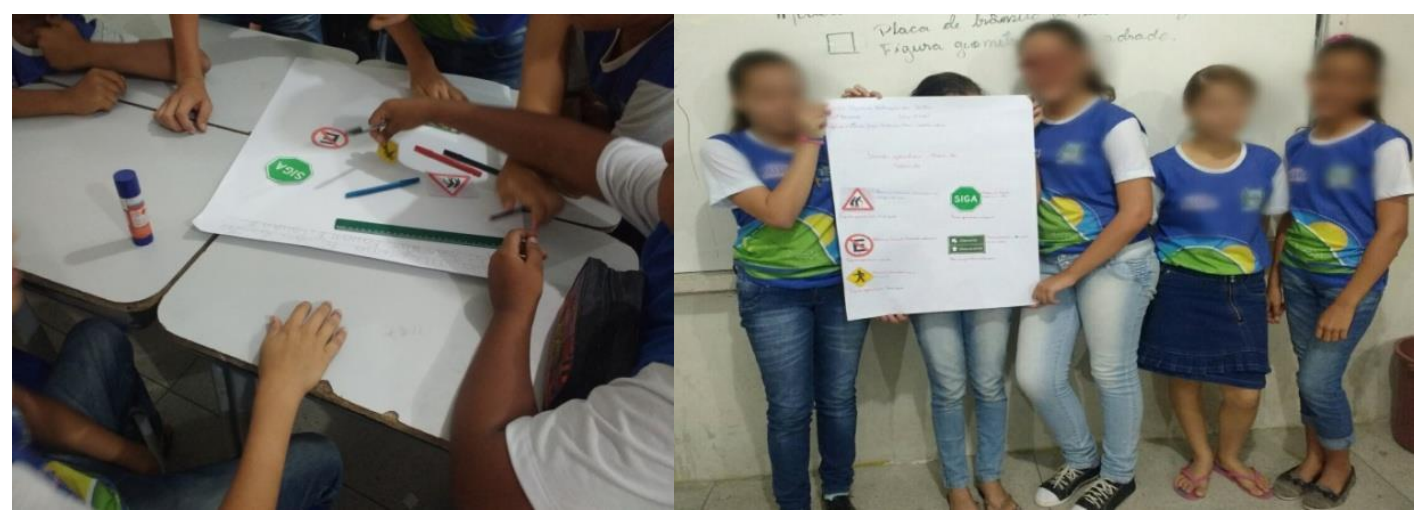

Os estudantes além de relacionarem o tema transversal à matemática tiveram a oportunidade de trabalhar em grupo e desenvolver a criatividade na construção dos cartazes, atentando para a importância da observação das placas no trânsito.

\title{
Considerações
}


A abordagem das formas geométricas através das placas de sinalização de trânsito proporcionou aos estudantes relacionar o conceito matemático com seu contexto diário. Essa abordagem transversal permitiu aos alunos além da construção do conhecimento matemático, a compreensão da importância das placas de trânsito na prevenção de acidentes.

Com o tema transversal relacionado a trânsito é possível abordar outros conceitos matemáticos como, gráficos, tabelas, média aritmética, entre outros. A abordagem desses temas pode contribuir para a compreensão do conteúdo e promover a sensibilização dos estudantes em relação a temática da educação no trânsito.

\section{Referências}

ALMEIDA, Marcela Bandeira de Melo. Cidadania e temas transversais na escola. Disponível em: <http://www.pedagogia.com.br/artigos/temas_transversais/index.php?pagina=0> Acesso em: 02 de Nov. de 2018.

BANASZESKI, Alexandra Auziliero, ECCO, Idanir. Educação para o trânsito: Um olhar para o contexto escolar. 2009. Disponível em:

$<$ https://www.webartigos.com/artigos/educacao-para-o-transito-um-olhar-para-o-contextoescolar/15180> Acesso em 04 de Nov. de 2018.

BRASIL. Secretaria de Educação Fundamental. Parâmetros curricularesnacionais : Matemática / Secretaria de Educação Fundamental. - Brasília: MEC / SEF, 1998.

RANCAN, Graziele. Origami e tecnologia: investigando possibilidades para ensinar geometria no ensino fundamental. / GrazieleRancan. Porto Alegre, 2011. Disponível em: $<$ http://repositorio.pucrs.br/dspace/handle/10923/3101\#preview> Acesso em: 31 de Out. de 2018. 